\section{Rainer Lenhardt, Ozan Akca}

Received/Geliş Tarihi : 23.12.2014 Accepted/Kabul Tarihi : 13.01.2015

Journal of the Turkish Society of Intensive Care, published by Galenos Publishing Türk Yoğun Bakım Derneği Dergisi, Galenos Yayınevi tarafından basılmıștır.

ISSN: 2146-6416

Rainer Lenhardt, Ozan Akca,

University of Louisville, Department of Anesthesiology and Perioperative Medicine, Louisville, USA

Rainer Lenhardt M.D. (凶), University of Louisville, Department of Anesthesiology and Perioperative Medicine Louisville, USA

E-mail: rainer.lenhardt@louisville.edu Phone: +90 001 502-852-5851

Hyperglycemia in the Intensive Care Unit

\author{
Yoğun Bakım Ünitesinde Hiperglisemi
}

SUMMARY Hyperglycemia is frequently encountered in the intensive care unit. In this disease, after severe injury and during diabetes mellitus homeostasis is impaired; hyperglycemia, hypoglycemia and glycemic variability may ensue. These three states have been shown to independently increase mortality and morbidity. Patients with diabetics admitted to the intensive care unit tolerate higher blood glucose values without increase of mortality. Stress hyperglycemia may occur in patients with or without diabetes and has a strong association with increased mortality in the intensive care unit patients. Insulin is the drug of choice to treat hyperglycemia in the intensive care unit. In patients with moderate hyperglycemia a basal-bolus insulin concept can be used. Close glucose monitoring is of paramount importance throughout the intensive care unit stay of the patient. In the guidelines for glycemic control based on meta-analyses it was shown that a tight glycemic control does not have a significant mortality advantage over conventional treatment. Given the controversy about optimal blood glucose goals in the intensive care unit setting, it seems reasonable to target a blood glucose level around $140 \mathrm{mg} / \mathrm{dL}$ to avoid episodes of hypoglycemia and minimize glycemic variability. The closed loop system with continuous glucose monitoring and algorithm based insulin application by an infusion pump is a promising new concept with the potential to further reduce mortality and morbidity due to hyperglycemia, hypoglycemia and glycemic variability.
The goal of this review was to give a brief overview about pathophysiology of hyperglycemia and to summarize current guidelines for glycemic control in critically ill patients.

Key Words: Hyperglycemia, blood glucose control, intensive care unit

ÖZET Yoğun bakım ünitesinde hiperglisemiye sıklıkla rastlanmaktadır. Hastalık durumlarında ağır hasar sonrasında ve diyabetes mellitus sürecinde homeostaz bozulur, hiperglisemi, hipoglisemi ve glisemik değişkenlik meydana gelebilir. Bu üç durumun bağımsız olarak mortalite ve morbiditeyi artırdığı gösterilmiştir. Stres hiperglisemisi diyabetik veya diyabetik olmayan hastalarda görülebilir ve yoğun bakım hastalarındaki artmış mortaliteyle güçlü ilişkiye sahiptir. Yoğun bakım ünitesinde hiperglisemi tedavisinde tercih edilen ilaç insülindir. Orta derecede hiperglisemisi olan hastalarda, bazalbolus insülin uygulaması kullanılabilir. Metaanalizlere dayanan glisemik kontrol kılavuzlarında sıkı glisemik kontrolün konvansiyonel tedaviye kıyasla mortalitede anlamlı fayda sağlamadığı gösterilmiştir. Yoğun bakım ünitesindeki kan glukoz hedefleri tartışmalı olmakla birlikte 140 $\mathrm{mg} / \mathrm{dl}$ civarında kan glukozu, hipoglisemi ataklarından kaçınmak ve glisemik değişkenliği en aza indirmek kabul edilebilir hedeflerdir. Bu derlemede hipergliseminin patofizyolojisine genel bir bakış yapılması ve kritik hastalardaki glisemik kontrol için son kılavuzların özetlenmesi amaçlanmıştır.

Anahtar Kelimeler: Hiperglisemi, kan glukoz kontrolü, yoğun bakım 


\section{Introduction}

Hyperglycemia is encountered frequently in the intensive care unit (ICU) setting. Hyperglycemia may be due to preexisting and known diabetes. It can also be seen in patients who were unaware of having diabetes. In Turkey, diabetes has a prevalence of about $7.3 \%$.

In addition, hyperglycemia can be observed in patients who are not diabetics, but have an increased resistance to insulin due to stress of injury or critical illness. This is termed stress hyperglycemia. Combinations of stress hyperglycemia and diabetes do occur and can raise blood glucose values even further.

Hyperglycemia in the critical care unit has been associated with increased morbidity and mortality. In early randomized controlled trials, strict normoglycemia (80-110 $\mathrm{mg} / \mathrm{dll}$ ) by use of insulin infusions has shown a reduction in morbidity and mortality $(1,2)$. However, these results could not be reproduced in later multicenter trial (3). A recent metaanalysis revealed that tight glycemic control does not have a mortality advantage over a less stringent glycemic control in ICU patients (4).

Various speculations have nurtured theories about the discrepancy in patient outcomes between the older and the later studies. One possible explanation may lie in the significantly higher incidence of severe $(<40 \mathrm{mg} / \mathrm{dl})$ hypoglycemic events in patients undergoing tight glycemic control. Griesdale showed in his meta-analysis that hypoglycemia was six times more likely to occur during tight glycemic control compared with conventional glucose control (5).

Glycemic variability is considered yet another domain of glycemic control besides hyper-and hypoglycemia. There is an independent association between glycemic variability and mortality in critically ill patients according to various observational studies (6-8).

The goal of this review is to give a brief overview about pathophysiology of hyperglycemia, address the three domains of glycemic control and summarize current guidelines for glycemic control in critically ill patients.

\section{Pathophysiology}

Hyperglycemia occurs as main laboratory aberration in diabetes mellitus type- 1 and type- 2 and during gestational diabetes. Type- 1 diabetes is defined by insufficient insulin production due to a ß-cell disorder. In contrast, the etiology of type-2 diabetes is a combination of $ß$-cell defects and insulin resistance.

Acute, sustained hyperglycemia can be triggered by critical illness or severe trauma, also termed stress hyperglycemia. The development of stress hyperglycemia is a result of an imbalance between insulin and counter-regulatory hormones.
Initial stress provokes an increase in catecholamine, cortisol, glucagon and growth hormone secretions resulting in excessive hepatic glycogenolysis and gluconeogenesis and insulin resistance. The resulting hyperglycemia induces an increase in pro-inflammatory cytokine production, including IL-1, IL-6 and TNF-alpha (9). Pro-inflammatory cytokines, in turn, may alter insulin receptor signaling thereby increasing insulin resistance.

Hyperglycemia can be seen as adaptive response to injury or critical illness. Glucose is delivered to vital tissues such as brain and blood cells, while glucose uptake is diminished in insulin dependent tissues such as skeletal muscle and fatty tissues.

However, sustained hyperglycemia causes an increase of radical oxygen species (ROS) with subsequent mitochondrial dysfunction (10). The mitochondrial dysfunction and change in ultrastructure is thought to be a culprit of organ dysfunction and may contribute to an increase of mortality associated with stress hyperglycemia (11).

Hyperglycemia also induces changes in blood coagulation, immune cell function and wound healing (12). On a cellular level, hyperglycemia triggers endothelial dysfunction inhibiting nitric oxide production. Monocytes exert enhanced cytokine production under the influence of hyperglycemia as do macrophages. In addition, hyperglycemia augments macrophage proliferation and activity and induces neutrophil dysfunction. Lastly, hyperglycemia inhibits T cell proliferation and blocks neutrophil tissue infiltration, all of which can lead to impaired wound healing (13).

\section{Domains of Glycemic Control}

Under normal conditions glycemic homeostasis is tightly controlled. In disease states or after severe injury and during diabetes mellitus homeostasis is impaired and hyperglycemia, hypoglycemia and glycemic variability can ensue. These three domains of glycemic control have been associated independently with increased risk of death in critically ill patients. Underlying diabetes may modulate the relation of the three domains of glycemic control in this patient population.

\section{Hyperglycemia}

Diabetes has been defined as a fasting plasma glucose of $>126 \mathrm{mg} / \mathrm{dl}$ and a casual plasma glucose concentration of $>200 \mathrm{mg} / \mathrm{dl}$ or a 2 hour plasma glucose $>200 \mathrm{mg} / \mathrm{dl}$ after oral glucose tolerance test (14). Likewise, a hemoglobin A1C of $>6 \%$ can be classified as diabetes mellitus (15). Diabetics mainly suffer from long term sequelae including an increased risk of myocardial infarction, stroke, nephropathy, foot ulcer, retinopathy and neuropathy. Of note, it has been shown that patients with known diabetes have a lower mortality 
during critical illness compared to patients with previously undiagnosed diabetes (16).

Hyperglycemia due to stress from severe disease or trauma has been defined as plasma glucose levels of $>140$ $\mathrm{mg} / \mathrm{dl}$ (17). Stress hyperglycemia can occur in diabetic and non-diabetic patients alike and has a strong association with increased mortality in the ICU population (17-19).

In addition, hyperglycemia on admission appears to be associated with an increase in long term mortality by a factor of 1.5 and predicts an increased risk to subsequently develop diabetes (20).

\section{Hypoglycemia}

Severe hypoglycemia was originally defined as plasma glucose level $<40 \mathrm{mg} / \mathrm{dl}$. Lately, the definition has been revised to higher levels, marking a plasma glucose of $<70$ $\mathrm{mg} / \mathrm{dl}$ hypoglycemia $(21,22)$.

During the last decade, insulin treatment has become standard of care in critically ill patients with hyperglycemia. As a side effect, insulin treatment increases the risk of hypoglycemia in the course of the patient's ICU stay. This adverse effect of insulin has been shown in various randomized controlled trials comparing standard insulin therapy with tight glycemic control $(1-3,23)$. Predisposing factors of hypoglycemia in association with mortality have been identified as ICU length of stay, diabetes, female gender, mechanical ventilation and APACHE scores (24).

In contrast, spontaneous episodes of severe hypoglycemia are rare and may be encountered in acute liver failure or adrenal failure due to septic shock and renal replacement therapy.

Hypoglycemia has been identified as an independent risk factor for mortality and for morbidity (25-28). In the ICU setting it is particularly difficult to identify symptoms of hypoglycemia such as seizures, confusion or dysarthria as these symptoms may be disguised by sedation or coma. One study demonstrated that the more severe hypoglycemia is, the higher the risk of death (28).

\section{Glycemic Variability}

Blood glucose values vary throughout a day. Glucose variability can be defined as the coefficient of variation of blood glucose values measured daily in predefined frequencies. Glycemic variability has been associated with increased mortality in ICU patients $(6,8,29,30)$. However, all the available studies were observational in nature and do not allow to draw a causal conclusion.

Is there a relationship between the three domains of glycemic control in critically ill patients with and without diabetes?
In a recent large retrospective analysis of prospectively collected data Krinsley et al. have demonstrated slightly different nadirs of blood glucose values associated with lowest mortality (31).

Non-diabetic patients in the ICU appeared to have the lowest risk of mortality at mean blood glucose values between 80 and $140 \mathrm{mg} / \mathrm{dl}$. Blood glucose values above or below this range were associated with increased mortality. Elevated glycemic variability as defined by coefficient of variation of the mean glucose value was also associated with increased risk of mortality.

Interestingly, in diabetic patients admitted to the ICU, mean blood glucose levels between 110 to $180 \mathrm{mg} / \mathrm{dl}$ were associated with lowest mortality, whereas values at a range of $80-110 \mathrm{mg} / \mathrm{dl}$ increased the risk of mortality. Hypoglycemia as defined by $<70 \mathrm{mg} / \mathrm{dl}$ also raised the risk of mortality, while glycemic variability of $>20 \%$ (coefficient of variation) did not alter the risk of mortality in diabetics.

Taken together these data suggest that there appears to be a J-shaped curve of mortality with slightly different ranges of lowest mortality in diabetics compared with nondiabetics. Diabetics in the critical care setting seem to benefit from higher glucose target ranges with a low cut off point of $110 \mathrm{mg} / \mathrm{dl}$, while non-diabetics may tolerate a lower mean blood glucose range (80-140 mg/dl). Hypoglycemia was linked to higher mortality in both patient groups. Glycemic variability seems to affect mortality in non-diabetics, but not in diabetics. These results are in contrast to a more recent study, suggesting that there also is an association of glycemic variability in diabetics (OR 1,15), although lower compared to non-diabetics (OR 1,37) (32).

Given the retrospective nature of the study, it may be premature to draw conclusions for optimal treatment of both ICU populations and randomized controlled interventional trials will be needed to clarify the impact of potential treatment differences (33).

\section{Guidelines for Glycemic Control in Critically III Patients}

There is lack of consensus for the ideal blood glucose target for critically ill patients due to different outcomes in randomized controlled trials comparing tight glycemic control (80-110 mg/dl) with conventional glucose management (13). However, various organizations have published guidelines for glycemic control based on meta-analyses that have not shown a significant mortality advantage of tight glycemic control over conventional treatment $(5,34,35)$.

The Surviving Sepsis Campaign recommends to treat hyperglycemia in critically ill patients when two consecutive blood glucose levels are $>180 \mathrm{mg} / \mathrm{dl}$ (36). In addition, they recommend that blood glucose values should be monitored 
every 1-2 $\mathrm{h}$ until glucose values and insulin infusion rates are stable, then every $4 \mathrm{~h}$ thereafter. Earlier recommendations have suggested to keep critically ill patients in the range of $140-180 \mathrm{mg} / \mathrm{dl}(37,38)$.

Given the controversy about optimal blood glucose goals in the ICU setting, it seems reasonable to target a blood glucose level around $140 \mathrm{mg} / \mathrm{dl}$ with the secondary goal to avoid episodes of hypoglycemia and minimize glycemic variability. This may be accomplished the best by monitoring blood glucose every hour and by administration of an insulin infusion, if patient's blood glucose levels are consistently above $180 \mathrm{mg} / \mathrm{dl}$.

An insulin infusion system should be applied by using a validated insulin titration program, ideally software driven, as computer based algorithms have been shown to allow more accurate insulin titration and tighter glycemic control (39). Likewise, it is important to have accurate monitoring technology available, preferably using arterial or venous blood samples as opposed to finger sticks. Concomitantly important, there should be appropriate staffing, and there should be emphasis on enteral nutrition support. Finally, there should be a protocol in place to prevent and treat episodes of hypoglycemia (40).

In diabetic patients admitted to the ICU, oral anti-glycemic drugs should be discontinued. Instead, patients should receive insulin under close blood glucose monitoring. If blood glucose levels stay below $180 \mathrm{mg} / \mathrm{dl}$, a basal-bolus insulin regimen can be started. This regimen consists of a long lasting basal insulin such as insulin glargin or insulin detemir and bolus insulin during meals. If a patient is on continuous enteral nutrition bolus insulin should be given 4 times a day with constant intervals. The basal-bolus insulin concept has been shown to be superior to a sliding scale insulin concept to reach target blood glucose values of $<140 \mathrm{mg} / \mathrm{dl}$ in both medical and surgical patients (41).

\section{The Future}

Blood glucose monitoring is stressful for patients (given hourly fingersticks) and time consuming for nurses. Automated continuous glucose monitoring systems (CGM) are currently in development $(42,43)$. Continuous glucose monitoring systems can be combined with insulin infusion pumps to form a closed loop system. Several studies have shown that a closed loop system alias an "artificial pancreas" may become a reasonable tool to avoid the three domains of glycemic control and maintain normoglycemia without major swings $(44,45)$.

Closed loop systems will eventually allow us to determine ideal blood glucose levels in various patient populations admitted to a critical care unit. In addition, by keeping blood glucose levels fairly constant, we will be able to predictably determine, if mortality and morbidity can be further reduced in the future. One study has already shown to reduce surgical site infections by using an artificial pancreas (46).

\section{Summary}

In summary, the three domains of glycemic control, namely hyperglycemia, hypoglycemia and glycemic variability have been shown to independently increase mortality and morbidity. Diabetics admitted to the ICU tolerate higher blood glucose values (up to $180 \mathrm{mg} / \mathrm{dl}$ ) without increase of mortality.

Insulin is the drug of choice to treat hyperglycemia in the ICU setting. In patients with moderate hyperglycemia $(<180$ $\mathrm{mg} / \mathrm{dll}$ ), a basal-bolus insulin concept can be used. Close glucose monitoring is of paramount importance throughout the ICU (and hospital) stay of the patient.

The closed loop system with continuous glucose monitoring and algorithm based insulin application by an infusion pump is a promising new concept with the potential to further reduce mortality and morbidity due to the three domains of glycemic control.

\section{References}

1. van den Berghe $G$, Wouters P, Weekers F, Verwaest C, Bruyninckx F, Schetz M, et al. Intensive insulin therapy in critically ill patients. The New England Journal of Medicine 2001;345:1359-67.

2. Van den Berghe G, Wilmer A, Hermans G, Meersseman W, Wouters PJ, Milants I, et al. Intensive insulin therapy in the medical ICU. N Engl J Med 2006;354:449-61.

3. NICE-SUGAR Study Investigators, Finfer S, Chittock DR, Su SY-S, Blair D, Foster $\mathrm{D}$, et al. Intensive versus conventional glucose control in critically ill patients. N Engl J Med 2009;360:1283-97.
4. Kansagara D, Fu R, Freeman M, Wolf F, Helfand M. Intensive insulin therapy in hospitalized patients: a systematic review. Ann Intern Med 2011;154:268-82.

5. Griesdale D, de Souza R, van Dam R, Heyland D, Cook D, Malhotra A, et al. Intensive insulin therapy and mortality among critically ill patients: a meta-analysis including NICE-SUGAR study data. CMAJ : Canadian Medical Association journal $=$ journal de I'Association medicale canadienne 2009.

6. Egi M, Bellomo R, Stachowski E, French CJ, Hart G. Variability of blood glucose concentration and short-term mortality in critically ill patients. Anesthesiology 2006;105:244-52
7. Krinsley JS. Glycemic variability: a strong independent predictor of mortality in critically ill patients. Crit Care Med 2008;36:3008-13.

8. Hermanides J, Vriesendorp TM, Bosman RJ, Zandstra DF, Hoekstra JB, DeVries $\mathrm{JH}$. Glucose variability is associated with intensive care unit mortality. Crit Care Med 2010;38:838-42.

9. Esposito K, Nappo F, Marfella R, Giugliano G, Giugliano F, Ciotola M, et al. Inflammatory cytokine concentrations are acutely increased by hyperglycemia in humans: role of oxidative stress. Circulation 2002;106:2067-72.

10. Stentz FB, Umpierrez GE, Cuervo R, Kitabchi AE. Proinflammatory cytokines, markers of cardiovascular risks, oxidative stress, and lipid peroxidation in patients 
with hyperglycemic crises. Diabetes 2004:53:2079-86.

11. Vanhorebeek I, De Vos R, Mesotten D, Wouters PJ, De Wolf-Peeters C, Van den Berghe G. Protection of hepatocyte mitochondrial ultrastructure and function by strict blood glucose control with insulin in critically ill patients. Lancet 2005;365:53-9.

12. Stegenga ME, van der Crabben SN, Blümer RME, Levi M, Meijers JCM, Serlie MJ, et al. Hyperglycemia enhances coagulation and reduces neutrophil degranulation, whereas hyperinsulinemia inhibits fibrinolysis during human endotoxemia. Blood 2008;112:82-9

13. Xiu F, Stanojcic M, Diao L, Jeschke MG. Stress hyperglycemia, insulin treatment, and innate immune cells. Int J Endocrinol 2014;2014:486403.

14. American Diabetes Association. Executive summary: Standards of medical care in diabetes-2014. Diabetes Care 2014;37:513.

15. Selvin E, Steffes MW, Zhu H, Matsushita $\mathrm{K}$, Wagenknecht L, Pankow J, et al. Glycated hemoglobin, diabetes, and cardiovascular risk in nondiabetic adults. N Engl J Med 2010;362:800-11.

16. Umpierrez GE, Isaacs SD, Bazargan N, You $X$, Thaler LM, Kitabchi AE. Hyperglycemia: an independent marker of in-hospital mortality in patients with undiagnosed diabetes. Journal of Clinical Endocrinology \& Metabolism 2002;87:978-82.

17. Dungan KM, Braithwaite SS, Preiser J-C. Stress hyperglycaemia. Lancet 2009:373:1798-807.

18. Krinsley JS. Association between hyperglycemia and increased hospital mortality in a heterogeneous population of critically ill patients. Mayo Clin Proc 2003:78:1471-8.

19. Falciglia M, Freyberg RW, Almenoff PL, D'Alessio DA, Render ML. Hyperglycemiarelated mortality in critically ill patients varies with admission diagnosis*. Crit Care Med 2009;37:3001-9.

20. McAllister DA, Hughes KA, Lone N, Mills NL, Sattar N, McKnight J, et al. Stress hyperglycaemia in hospitalised patients and their 3-year risk of diabetes: a Scottish retrospective cohort study. PLoS Med 2014;11:1001708.

21. Cryer PE, Davis SN, Shamoon H. Hypoglycemia in diabetes. Diabetes Care 2003:26:1902-12.

22. Seaquist ER, Anderson J, Childs B, Cryer $P$, Dagogo-Jack S, Fish L, et al. Hypoglycemia and diabetes: a report of a workgroup of the American Diabetes Association and the Endocrine Society. Diabetes Care 2013:36:1384-95.

23. Arabi YM, Dabbagh OC, Tamim HM, AlShimemeri AA, Memish ZA, Haddad SH, et al. Intensive versus conventional insulin therapy: A randomized controlled trial in medical and surgical critically ill patients* Crit Care Med 2008;36:3190-7.
24. Arabi YM, Tamim HM, Rishu AH. Hypoglycemia with intensive insulin therapy in critically ill patients: Predisposing factors and association with mortality*. Crit Care Med 2009;37:253644.

25. NICE-SUGAR Study Investigators, Finfer S, Liu B, Chittock DR, Norton R, Myburgh $J A$, et al. Hypoglycemia and risk of death in critically ill patients. N Engl J Med 2012;367:1108-18.

26. Hermanides J, Bosman RJ, Vriesendorp TM, Dotsch R, Rosendaal FR, Zandstra DF, et al. Hypoglycemia is associated with intensive care unit mortality. Crit Care Med 2010;38:1430-4

27. Vriesendorp TM, DeVries JH, Hoekstra JB. Hypoglycemia and strict glycemic control in critically ill patients. Curr Opin Crit Care 2008;14:397-402.

28. Egi M, Bellomo R, Stachowski E, French CJ, Hart GK, Taori G, et al. Hypoglycemia and outcome in critically ill patients. Mayo Clin Proc 2010;85:217-24.

29. Ali NA, O'Brien JM, Dungan K, Phillips G, Marsh CB, Lemeshow S, et al. Glucose variability and mortality in patients with sepsis. Crit Care Med 2008;36:2316-21.

30. Meyfroidt G, Keenan DM, Wang X, Wouters PJ, Veldhuis JD, Van den Berghe G. Dynamic characteristics of blood glucose time series during the course of critical illness: effects of intensive insulin therapy and relative association with mortality. Crit Care Med 2010;38:1021-9.

31. Krinsley JS, Egi M, Kiss A, Devendra AN, Schuetz P, Maurer PM, et al. Diabetic status and the relation of the three domains of glycemic control to mortality in critically ill patients: an international multicenter cohort study. Critical care (London, England) 2013;17:37.

32. Lanspa MJ, Dickerson J, Morris AH, Orme JF, Holmen J, Hirshberg EL. Coefficient of glucose variation is independently associated with mortality in critically ill patients receiving intravenous insulin. Critical care (London, England) 2014;18:86.

33. Finfer S, Billot L. Managing blood glucose in critically ill patients with or without diabetes. Critical care (London, England) 2013:17:134.

34. Friedrich JO, Chant C, Adhikari NK. Does intensive insulin therapy really reduce mortality in critically ill surgical patients? A reanalysis of meta-analytic data. Crit Care. 2010;14:324.

35. Marik PE, Preiser J-C. Toward understanding tight glycemic control in the ICU: a systematic review and metaanalysis. Chest 2010;137:544-51.

36. Dellinger RP, Levy MM, Rhodes A, Annane D, Gerlach H, Opal SM, et al. Surviving sepsis campaign: international guidelines for management of severe sepsis and septic shock, 2012. Intensive Care Med 2013;39:165-228.
37. Canadian Diabetes Association Clinical Practice Guidelines Expert Committee, Houlden R, Capes S, Clement M, Miller D. In-hospital management of diabetes. Can J Diabetes 2013;37 Suppl 1:77-81.

38. Moghissi ES, Korytkowski MT, DiNardo M, Einhorn D, Hellman R, Hirsch IB, et al. American Association of Clinical Endocrinologists and American Diabetes Association consensus statement on inpatient glycemic control. Endocrine practice : official journal of the American College of Endocrinology and the American Association of Clinical Endocrinologists 2009;15:353-69.

39. Newton CA, Smiley D, Bode BW, Kitabchi AE, Davidson PC, Jacobs S, et al. A comparison study of continuous insulin infusion protocols in the medical intensive care unit: computer-guided vs. standard column-based algorithms. Journal of hospital medicine (Online) 2010;5:432-7.

40. Jacobi J, Bircher N, Krinsley J, Agus M, Braithwaite SS, Deutschman C, et al. Guidelines for the use of an insulin infusion for the management of hyperglycemia in critically ill patients. Crit Care Med 2012;40:3251-76.

41. Umpierrez GE, Smiley D, Jacobs S, Peng L, Temponi A, Mulligan P, et al. Randomized study of basal-bolus insulin therapy in the inpatient management of patients with type 2 diabetes undergoing general surgery (RABBIT 2 surgery). Diabetes Care 2011;34:256-61.

42. Al-Halhouli A, Demming S, Alahmad L, Llobera A, Büttgenbach S. An in-line photonic biosensor for monitoring of glucose concentrations. Sensors (Basel) 2014;14:15749-59.

43. Boom DT, Sechterberger MK, Rijkenberg S, Kreder S, Bosman RJ, Wester J, et al. Insulin treatment guided by subcutaneous continuous glucose monitoring compared to frequent point-of-care measurement in critically ill patients: a randomized controlled trial. Critical care (London, England) 2014;18:453.

44. Takahashi G, Sato N, Matsumoto N, Shozushima T, Hoshikawa K, Akitomi S, et al. Preliminary study on glucose control with an artificial pancreas in postoperative sepsis patients. Eur Surg Res 2011:47:32-8.

45. Tsukamoto $Y$, Kinoshita $Y$, Kitagawa $H$, Munekage M, Munekage E, Takezaki Y, et al. Evaluation of a novel artificial pancreas: closed loop glycemic control system with continuous blood glucose monitoring. Artif Organs 2013;37:67-73.

46. Okabayashi T, Shima Y, Sumiyoshi T, Kozuki A, Tokumaru T, liyama T, et al. Intensive versus intermediate glucose control in surgical intensive care unit patients. Diabetes Care 2014;37:1516-24. 